\title{
sciendo \\ THE INFLUENCE
OF TEMPERATURE ON CHANGES \\ IN THE DISTINGUISHING FEATURES \\ OF THE USABLE QUALITY \\ OF SOYBEAN MEAL
}

DOI 10.2478/ntpe-2018-0047

\author{
dr inż. Beata Drzewieniecka \\ dr inż. Jan Drzewieniecki \\ Maritime University of Szczecin, Poland \\ Ing. Miroslav Blatnický, PhD \\ University of Zilina, Slovak Republic
}

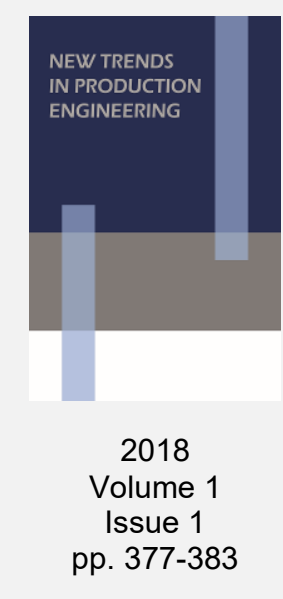

\begin{abstract}
Soybean meal is one of the fodder components. It is a by-product of the production of soybean oil. Soybean meal is a specific cargo due to changes that may occur in it during transport processes. These changes are subject to many distinguishing features of usable quality inter alia fat and fatty acid content. The temperature and size of the soybean meal particles are among the factors influencing the transformations. The article presents the results of research on soybean meal and its individual fractions and the impact of selected indicators on the quality changes of this cargo. The results depend on the conditions corresponding to those that occur during the storage, handling and transport processes. The dependencies between them have been determined. The performed research allowed to determine the type and scope of changes taking place in this cargo under the influence of temperature. The results of the study showed that as the temperature rises, the fatty acid content in the soybean meal decreased during storage for a given period of 30 days.
\end{abstract}

Keywords: soybean meal, fatty acids, acid number, peroxide value, transport processes, fodder

\section{INTRODUCTION}

The popularity of soybean meal as the one of the components of compound fodders is very large. Due to its high nutritional value, it is used for the production of fodders. This product is considered to be specific cargo due to its sensitivity to external factors: temperature and humidity. They have a significant impact on changes in the usable quality parameters including fatty acids (Thakkar, 2014, Orsavova et al., 2015).

Soybean meal is composed of many ingredients. Fats are the most susceptible to adverse changes occurring during storage. Under the influence of oxygen from the air, light and temperature there are undergoing changes through autoxidation or photo-oxidation. According to Gunstone photosensitized oxidation is faster than autoxidation (Gunstone, 1984).

The hydro-peroxides formed in the lipid oxidation process are very unstable and can undergo various transformations. Due to the disruption of the carbon chain, short-chain products are formed, such as: hydrocarbons, aldehydes, ketones, esters, lactones, alcohols and ethers, which may exist as saturated or unsaturated compounds (Lempka, 1985, Barowicz, 1999). One of the most important factors is the product's resistance to oxidation processes (Minkowski, 2011). In turn, the factors that reduce the oxidative stability of the product is higher temperature (Vaidya and Jong-Bang, 2013).

Autoxidation belongs to extremely complicated processes. The reason for this is the exceptional lability of intermediates, the complex effect of antioxidants and the simultaneous reaction of photosensitized oxidation. Although, all unsaturated lipids are oxidized, the problem of autoxidation is reduced to the unsaturated fatty acid hydrocarbon chain. Linoleic acid oxidizes $10 \div 40$ times faster than oleic acid, while linolenic acid is $2 \div 4$ times faster than linoleic acid (Lempka, 1985, Sikorski, 1994). The literature review shows that as the temperature increases, the oxidation rate increases and the induction period is shortened (Lempka, 1985, 
Barowicz, 1999, (Drozdowski, 1988, Matyka, 2000, Mateos et al., 1996). The process of oxidation of linoleic acid can occur at temperature of minus $20^{\circ} \mathrm{C}$.

The chemical structure of the soybean meal components is changed by autoxidation, which makes the vitamins lose their activity, dyes - color and fats acquire an unpleasant odor. This process starts in the soybean meal from the creation of free radicals which occurs as a result of the action of high temperature, radiation, light or metal ions with catalytic properties, especially iron, copper and zinc (Barowicz, 1999).

Peroxides belong to toxic compounds. Their principal harmful action is to destroy or inactivate some fodder ingredients. Peroxides also increase the rate of autoxidation of dyes, they can cause denaturation or polymerization of proteins, and as a consequence, decrease of digestibility and assimilation of fodder (Kwietniak and Harenza, 1990, Lempka, 1985).

Oxidation of fats causes a decrease in the nutritional value of fodder, which is noted (Busboom et al., 1991): rancid taste - peroxides give fodder a characteristic taste, formation of toxic compounds - peroxides, ketones and aldehydes, which in greater amounts exhibit toxic effects, adverse health effects and production results, occurrence of loss of fat-soluble vitamins subject to oxidative processes, reduction of protein content (amino acids) - mainly by creating hard to digest bridges between protein molecules that make the combined molecules indigestible.

The longtime of transporting soybean meal by sea and specific microclimatic conditions occurring in ship's cargo holds, are conducive to unfavorable changes in fats. The fat content in soybean meal varies and amounts, according to various authors: $2 \%$ (Chachułowa, 1997); 1.5\% (Dudley-Cash, 1996); 1.7\% (Wong, 1989); 1.4\% (Lempka, 1985); 1.3\% (Britzman, 1994); 1,70 (Baize, 2000); 2.67\% (Drzewieniecka, 2017).

Among of many ingredients included in soybean meal, fats are most susceptible to adverse changes. During transport processes, under the influence of air, light and temperature, they change through autoxidation or photo-oxidation. The composition of fatty acids can be varied within a wide range, as it depends on many factors, including the soybean grade from which soybean meal is produced and soybean cultivation environments (Sikorski, 1994, Jung et al., 1997).

Soybean oil contains relatively low saturated fatty acids (about 15\%), and has a high content of unsaturated acids (about 85\%) (Mińkowski et al., 2011), (Nederal et al., 2012, Kearney, 2010). Soybean oil contains from 7 to $13 \%$ of saturated acids (Drozdowski, 1988). Research conducted by these authors has proved that the use of soybean meal or soybean oil in fodder mixtures used in feeding fattening pigs, can increase the content of poly-unsaturated fatty acids in the fat of ham and lower the cholesterol level in ham muscles. The share of soybean meal in feeding pigs caused the increase of fatty acids: linoleic and linolenic, which from the nutritional point of view is beneficial for human as a consumer (Mińkowski et al., 2011).

The significant influence of use of oilseed plants on increase in the content of essential unsaturated fatty acids (EFA) was also reported by Busboom and Myer (Busboom et al., 1991, Myer et al., 1992). The use of soybean oil in fodder mixtures contributed to an increase in the content of linoleic and linolenic acid, while reducing the amount of palmitic and stearic acid.

Essential unsaturated fatty acids (EFAs), which are included in the families of $n-6$ linoleic acid and linolenic acid $n-3$, have a high biological value. Soybean oil contains about $50 \%$ of EFA. Essential unsaturated fatty acids from the n-3 family are of great anti-atherosclerotic importance, as being components of cell membranes, they play a particularly important role in the transport and metabolism of cholesterol, lowering its content in blood (Sikorski, 1994, (Thakkar, 2014, Rabrenović et al., 2014).

The acid number is the most commonly used, non-selective indicator in fat characteristics. The acid number indicates the freshness of soybean meal. The increase in the value of the acid number is proof of the progressive hydrolysis of fat contained in soybean meal (Walczyński, 1993). Its value after 45 days at temp. of $65^{\circ} \mathrm{C}$ was $1.5 \mathrm{mg} \mathrm{KOH} / \mathrm{g}$ (Jung et al., 1997).

Unfavorable changes occurring in fats acquire a special meaning in the case of greasy fodder mixtures. With the extension of storage time, the value of acid and peroxide number increases (Matyka, 2000). 
Research on the antioxidant effect in fodder results (Barowicz, 1999), that the acid and peroxide values of rapeseed meal fat, stored in bulk without the addition of BHT, were increased by 2-3 fold after 20 days of storage. The acid number increased from 3.1 to $9.1 \mathrm{mg}$ $\mathrm{KOH} / \mathrm{g}$, and the peroxide value from 4.3 to $9.9 \mathrm{mM} \mathrm{O}_{2} / \mathrm{kg}$. Stabilization of this soybean meal by BHT reduced the formation of free fatty acids and peroxides: LK - increased from 3.1 to 4.2 $\mathrm{mg} \mathrm{KOH} / \mathrm{g}$, and $\mathrm{LN}$ - from 4.1 to $5.0 \mathrm{mM} \mathrm{O}_{2} / \mathrm{kg}$. On further storage of soybean meal, a gradual increase in the value of these numbers took place. Peroxides are the primary and unstable oxidation products, so the peroxide value is characterized by the degree of fat oxidation at the initial stage of oxidation. With the storage time, the peroxide number in the soybean meal increased. Its value after 45 days at temp. of $65^{\circ} \mathrm{C}$ was $1.5 \mathrm{mM} \mathrm{O} / \mathrm{kg}$ (Jung et al., 1997).

\section{RESEARCH METHODOLOGY}

The subject of research was soybean meal. The aim of the study was to determine the changes of fatty acids, the acid number and peroxide of natural soybean meal and its individual fractions under the influence of temperature. The tests were carried out in conditions corresponding to those occurring during the course of transport processes in temp. of 20 (I) and 40 (II) at the $10 \%$ of water content in soybean meal. Correlation was determined between the changes of individual discriminants and the external factor causing these changes.

The test results were statistically developed. The analysis of variance for single classification (ANOVA) was used for statistical analysis of the test results. In the case, when the assumption about homogeneity of variance was not met, there was applied a non-parametric alternative to the analysis of variance of simple classification, the Kruskal-Wallis test. In order to determine the statistical relationship between the analyzed variables, correlation coefficients were calculated.

Fractions with particle size larger than $3 \mathrm{~mm}(A)$ and with ranges of: 1.2-3mm (B), 0.4-1.2mm $(C), 0.25-0.4 \mathrm{~mm}(D), 0.1-0.25 \mathrm{~mm}(E), 0.075-0.1 \mathrm{~mm}(F)$, as well as fraction with particle size smaller than $0.075 \mathrm{~mm}(G)$ - dusty fraction were isolated from soybean meal. The grain composition of soybean meal was determined in accordance with PN-89/R-64798 by mechanical sieving of soybean meal samples. Changes in the composition of fatty acids of soybean meal were determined after 10, 20 and 30 days under conditions I and II.

The fatty acid composition was determined by gas chromatography, compatible with PN-EN ISO 6800:2002. The markings were made using the B-820 analyzer, which is part of the BÜCHI Labortechnik AG Swiss apparatus set. The acid number was determined in accordance with PN-EN ISO 660:2005. The peroxide number was determined in accordance with PN-EN ISO 3960:2005 (U).

The largest losses were found in the case of unsaturated fatty acids: oleic, linoleic and linolenic. Correlation coefficients between the content of these acids and the storage time were respectively $0.53 ; 0.52 ; 0.51$.

The studies showed the relationship between the change in fatty acid content in natural soybean meal and ambient temperature (Fig. 1). The dependence is shown on the example of linoleic acid, whose correlation coefficient was 0.73 . A significant relationship was found between the content of fatty acids: palmitic, stearic, oleic, linoleic, linolenic in fractions B, C, G of soybean meal and the size of particles. Correlation coefficients were: $0.77,0.61,0.81,0.85$ and 0.70 , respectively. In soybean meal with larger size of particles, the content of these fatty acids was lower.

During storage for 30 days at $20^{\circ} \mathrm{C}$ and relative humidity of $60 \%$, the acid number increased to $1.27 \mathrm{mg} \mathrm{KOH} / \mathrm{g}$, or $41.1 \%$ in relation to the initial value (Table 1). The initial content of the acid number of natural soybean meal was $0.90 \mathrm{mg} \mathrm{KOH} / \mathrm{g}$. At $40^{\circ} \mathrm{C}$ and $\varphi=95 \%$, the acid number increased to $1.55 \mathrm{mg} \mathrm{KOH} / \mathrm{g}$, i.e. by $72.2 \%$ in relation to the initial LK value (Table 1 ). The highest initial acid value of $1.20 \mathrm{mg} \mathrm{KOH} / \mathrm{g}$ had the $\mathrm{G}$ fraction - dusty fraction, while the smallest $\mathrm{C}$ fraction $-0.76 \mathrm{mg} \mathrm{KOH} / \mathrm{g}$.

After 30 days of storage of fraction $\mathrm{B}, \mathrm{C}$ and $\mathrm{G}$, at $20^{\circ} \mathrm{C}$ and relative humidity of $60 \%$, the acid number increased by $0.31 \mathrm{mg} \mathrm{KOH} / \mathrm{g}(36.5 \%$ relative to the initial value), respectively $0.26 \mathrm{mg}$ $\mathrm{KOH} / \mathrm{g}(34.2 \%)$ and $0.71 \mathrm{mg} \mathrm{KOH} / \mathrm{g}(59.2 \%)$ (Table 1). 


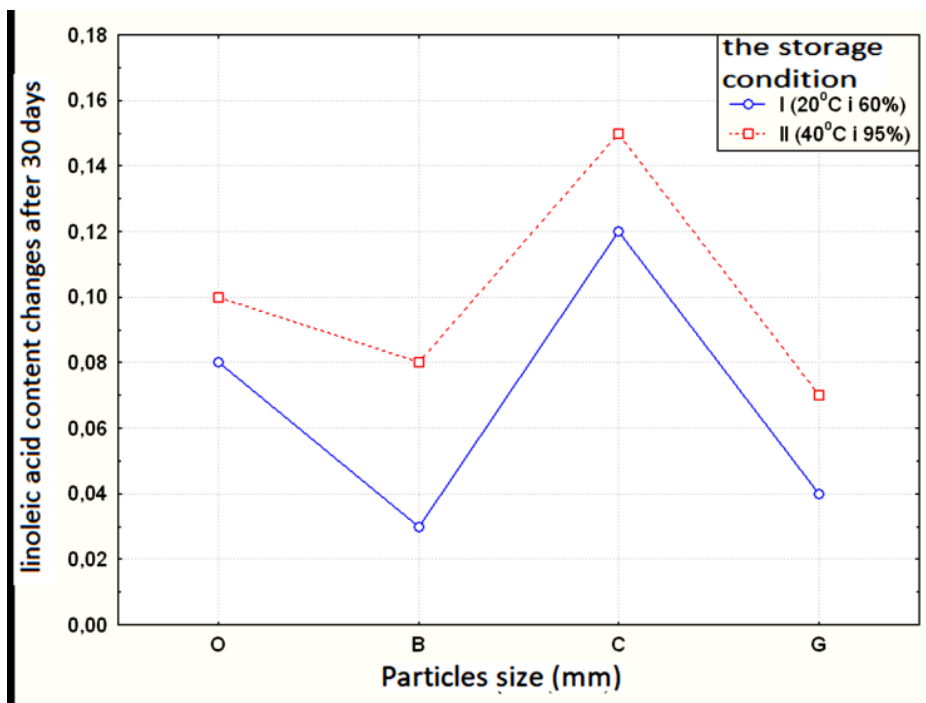

Fig. 1. Loss of linoleic acid content in natural soybean meal and its fractions stored in various crypto-climatic conditions.

Table 1.

Changes in the acid number and the peroxide number of soybean meal and its fractions $B, C$ and $\mathbf{G}$ after $\mathbf{3 0}$ days of storage under various cryptoclimatic conditions

\begin{tabular}{|c|c|c|c|c|c|}
\hline \multirow[b]{2}{*}{ Fractions } & \multirow[b]{2}{*}{$\begin{array}{c}\text { Cryptoclimatic storage } \\
\text { conditions }\end{array}$} & \multicolumn{2}{|c|}{$\begin{array}{c}\text { Acid number AN } \\
(\mathrm{mg} \mathrm{KOH} / \mathrm{g})\end{array}$} & \multicolumn{2}{|c|}{$\begin{array}{l}\text { Peroxide number PN } \\
\left(\mathrm{m} \mathrm{MO}_{2} / \mathrm{kg}\right)\end{array}$} \\
\hline & & $\begin{array}{l}\text { Initial } \\
\text { AN }\end{array}$ & $\begin{array}{l}\text { AN after } \\
30 \text { days } \\
\text { of storage }\end{array}$ & Initial PN & $\begin{array}{l}\text { PN after } \\
30 \text { days } \\
\text { of storage }\end{array}$ \\
\hline \multirow[t]{2}{*}{$\mathrm{O}$} & $\mathrm{t}=20^{\circ} \mathrm{C}, \varphi=60 \%$ & \multirow{2}{*}{0.90} & 1.27 & \multirow{2}{*}{0.56} & 0.99 \\
\hline & $\mathrm{t}=40^{\circ} \mathrm{C}, \varphi=95 \%$ & & 1.55 & & 1.99 \\
\hline \multirow{2}{*}{$\begin{array}{c}\mathrm{B} \\
(1.2-3 \mathrm{~mm}) \\
\end{array}$} & $\mathrm{t}=20^{\circ} \mathrm{C}, \varphi=60 \%$ & \multirow{2}{*}{0.85} & 1.16 & \multirow{2}{*}{0.48} & 0.69 \\
\hline & $\mathrm{t}=40^{\circ} \mathrm{C}, \varphi=95 \%$ & & 1.31 & & 1.02 \\
\hline \multirow{2}{*}{$\begin{array}{c}C \\
(0.4-1.2 \mathrm{~mm})\end{array}$} & $\mathrm{t}=20^{\circ} \mathrm{C}, \varphi=60 \%$ & \multirow{2}{*}{0.76} & 1.02 & \multirow{2}{*}{0.24} & 0.53 \\
\hline & $\mathrm{t}=40^{\circ} \mathrm{C}, \varphi=95 \%$ & & 1.22 & & 0.66 \\
\hline \multirow{2}{*}{$\begin{array}{c}\mathrm{G} \\
(<0.075 \mathrm{~mm})\end{array}$} & $\mathrm{t}=20^{\circ} \mathrm{C}, \varphi=60 \%$ & \multirow{2}{*}{1.20} & 1.91 & \multirow{2}{*}{0.51} & 0.78 \\
\hline & $\mathrm{t}=40^{\circ} \mathrm{C}, \varphi=95 \%$ & & 2.62 & & 1.14 \\
\hline
\end{tabular}

Source: own study.

In the second variant of soybean meal storage, the increase in the acid number in comparison with the variant I was significantly larger (Fig. 2).

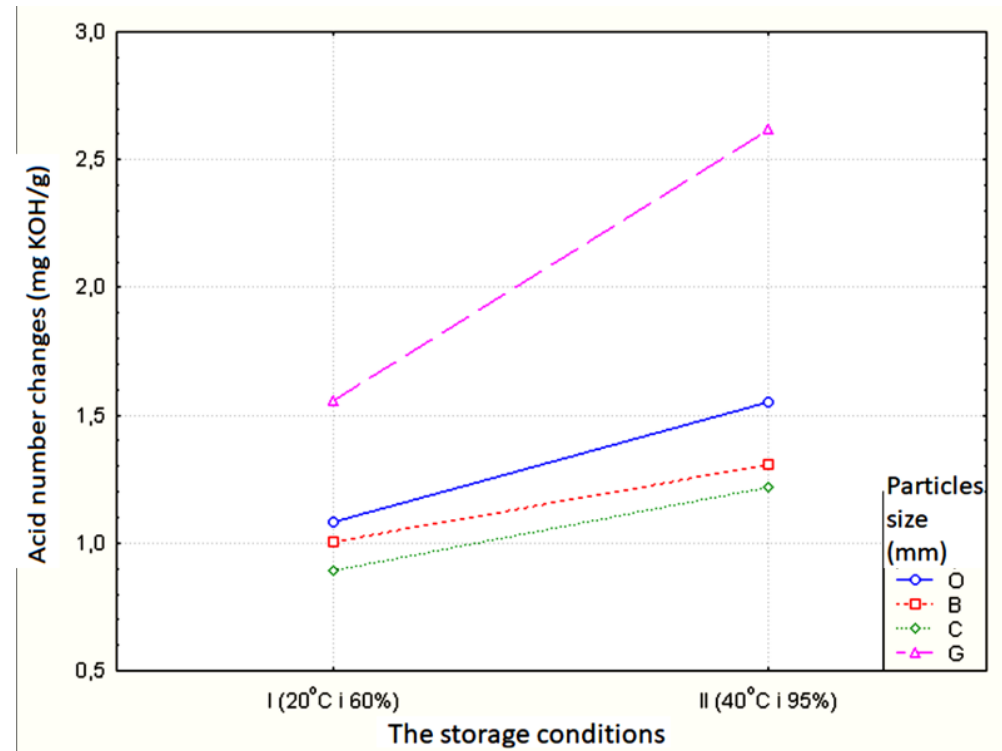

Fig. 2. Dependence of the acid number of natural soybean meal and its fractions on the storage conditions. 
In the fractions: B - LKE-2018-0047 increased to $1.31 \mathrm{mg} \mathrm{KOH} / \mathrm{g}$ (by $54.1 \%$ in relation to the initial value); $\mathrm{C}$ to $1.22 \mathrm{mg} \mathrm{KOH} / \mathrm{g}$ (by $60.5 \%$ ) and $\mathrm{G}$ to $2.62 \mathrm{mg} \mathrm{KOH} / \mathrm{g}$ (by $118.3 \%$ ) (Table 1). The correlation coefficient of the increase in the acid number of natural soybean meal and its fractions $(B, C, G)$ from the storage conditions was 0.52 .

During storage of soybean meal at $20^{\circ} \mathrm{C}$ and $60 \%$ of relative humidity, the peroxide value increased by $76.8 \%$, i.e. to $0.99 \mathrm{mM} \mathrm{O} / \mathrm{kg}$ (Table 1). The initial peroxide content of natural soybean meal was $0.56 \mathrm{mM} \mathrm{O}_{2} / \mathrm{kg}$ (Table 1). At a temp. of $40^{\circ} \mathrm{C}$ and high relative humidity of $95 \%$ - option II, the value of the peroxide number in natural soybean meal increased to 1.99 $\mathrm{mM} \mathrm{O} / \mathrm{kg}$, i.e. by $253.3 \%$ in relation to the initial value.

The relationship between the average values of the peroxide number of fractions $B, C$ and $G$ of soybean meal and its storage time under conditions I and II is shown in Fig. 3. The correlation coefficient of this relationship was 0.57 . The relationship between the values determining LN growth in natural soybean meal and its fractions expressed as a percentage and storage conditions is shown in Fig. 3 . The correlation coefficient of this relationship was 0.62 .

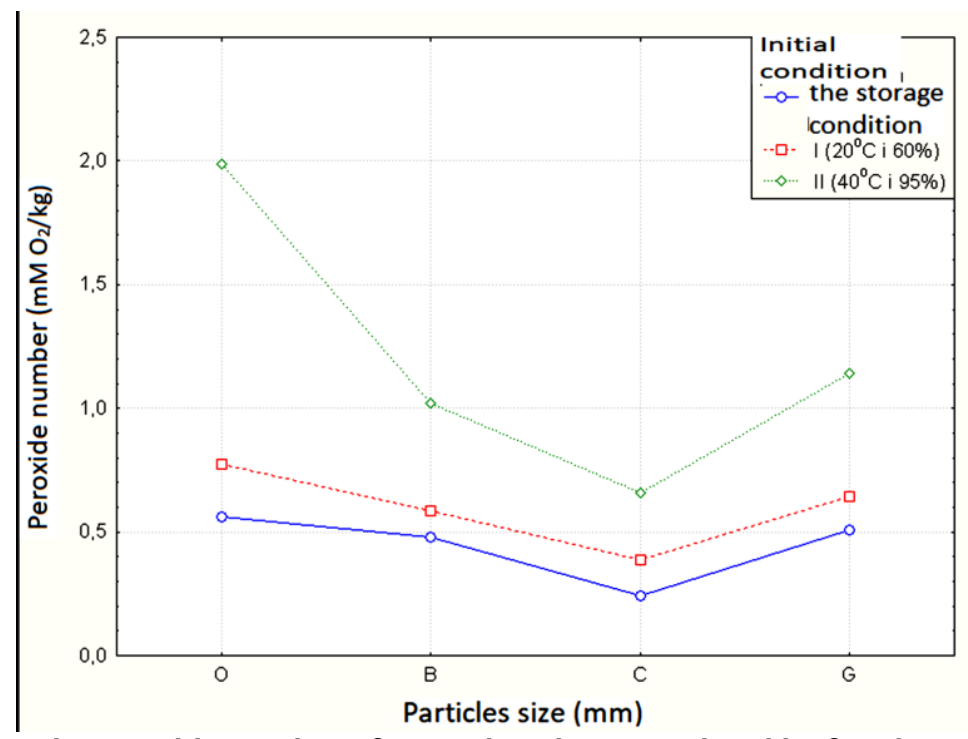

Fig. 3. Changes in peroxide number of natural soybean meal and its fractions during storage under various crypto-climatic conditions compared to initial values.

\section{DISCUSSION OF RESULTS}

Studies on the distinguishing features of usable quality of soybean meal in various temperature variants of 20 and 40 have been carried out. The adopted research model allowed obtaining data on the transformations of soybean meal in the range of temperatures and relative humidity maintained in subsequent stages of the supply chain. These conditions were similar to the most common ones during storage, cargo handling and carriage by various means of transport $\left(1-20^{\circ} \mathrm{C}\right.$ and relative humidity of $\left.60 \%\right)$ and extreme conditions occurring during transport of soybean meal in the ships' and barges' holds $\left(\mathrm{II}-40^{\circ} \mathrm{C}\right.$ and humidity relative $95 \%$ ). On the basis of tests carried out in two variants of temperature, it was found to have a significant impact on changes in the distinguishing features of usable quality of natural soybean meal and its fractions during storage. Increased temperature and relative humidity of the surroundings caused an increase in fatty acids, an increase in the acid number and peroxide number. The loss of fatty acids in natural fat of soybean meal: palmitic, stearic, oleic, linoleic, linolenic natural soybean meal, under conditions I $\left(\mathrm{t}=20^{\circ} \mathrm{C}, \varphi=60 \%\right)$, ranged from 4.4 to $31.6 \%$ in relation to the initial value. Under conditions II $\left(t=40^{\circ} \mathrm{C}, \varphi=95 \%\right)$, the largest losses concerned linolenic acid, while the smallest ones were oleic acid. The loss of these acids ranged from 7.3 to $47.4 \%$. The highest losses of fatty acids in the $B, C$ and $G$ fractions in conditions I and II concerned stearic acid (from 12.5 to $26.7 \%$ ), while the smallest concerned acids: palmitic (from 1.5 to $8 \%$ ), linoleic (from 2 to $9.7 \%$ ) and linolenic (from 5.8 to $10.5 \%$ ). The 
growth in the acid number was influenced by storage conditions. During storage for 30 days at $20^{\circ} \mathrm{C}$ and $60 \%$ of relative humidity, the acid value of natural soybean meal increased by $41.1 \%$ in relation to the initial value. In option II, the acid number value increased by $72.2 \%$. In the case of fraction $\mathrm{B}$, the value of the acid number in option I increased by $36.5 \%$, and in the option II - by $54.1 \%$. Fraction $\mathrm{C}$ had the lowest acid value of $0.76 \mathrm{mg} \mathrm{KOH} / \mathrm{g}$, which value under storage conditions I and II increased by $34.2 \%$ and $60.5 \%$ respectively. The highest value of the acid number was in fraction $\mathrm{G}$, amounting to $1.20 \mathrm{mg} \mathrm{KOH} / \mathrm{g}$. During storage, its value increased in the first option by $59.2 \%$, and in the second by $118.3 \%$. The increase in the acid number was observed during the 30 days storage time indicating a progressive hydrolysis of soybean meal lipids, and thus an increase in the content of free fatty acids. According to literature data (Lempka, 1985, Drozdowski, 1988, Sikorski, 1994, Matyka, 2000, Orsavova et al., 2015), polyunsaturated fatty acids, which are oxidized to a number of derivative compounds, are particularly easily released.

The study shows that during 30 days of storage time under conditions I, the peroxide value of natural soybean meal was $0.99 \mathrm{mM} \mathrm{O} / \mathrm{kg}$, i.e. it was higher by $0.43 \mathrm{mM} \mathrm{O}_{2} / \mathrm{kg}$ from the initial value, while in conditions II the value was peroxide value was $1.99 \mathrm{mM} \mathrm{O}_{2} / \mathrm{kg}$ (increased by $1.43 \mathrm{mM} \mathrm{O}_{2} / \mathrm{kg}$ ). During storage, the peroxide number of fraction $B$ was increased by $0.21 \mathrm{mM}$ $\mathrm{O}_{2} / \mathrm{kg}$ under conditions I and by $0.54 \mathrm{mM} \mathrm{O} / \mathrm{kg}$ under conditions II. In the case of fraction $\mathrm{C}$, LN was increased in conditions I and II, respectively: by 0.29 and $0.42 \mathrm{mM} \mathrm{O} / \mathrm{kg}$. The smallest fraction $\mathrm{G}$ was also characterized by an increase in the peroxide number by $0.27 \mathrm{mM} \mathrm{O} / \mathrm{kg}$ (option I) and by $0.63 \mathrm{mM} \mathrm{O}_{2} / \mathrm{kg}$ (option II).

\section{CONCLUSIONS}

Based on the results of the research and statistical analysis, the following conclusions were made:

1. The research results obtained in the study showed a significant effect of temperature on changes of fatty acids, the acid number and peroxide of soybean meal.

2. In the second variant of storage $\left(t=40^{\circ} \mathrm{C}\right.$ and $\left.\varphi=95 \%\right)$, in the natural soybean meal occurred significantly higher, than in the storage variant $\mathrm{I}\left(\mathrm{t}=20^{\circ} \mathrm{C}\right.$ and $\left.\varphi=60 \%\right)$, unfavorable changes of the following elements: fatty acids, acid number and peroxide value.

3. Similarly as in the case of natural soybean meal, also in the case of individual fractions at $t$ $=20^{\circ} \mathrm{C}$ and $\varphi=60 \%$, changes in the distinguishing features of usable quality were smaller than at $\mathrm{t}=40^{\circ} \mathrm{C}$ and $\varphi=95 \%$.

4. The size of soybean meal particles significantly influenced the distinguishing features of usable quality.

\section{REFERENCES}

Baize J.(2000). Global soybean meal sampling and analysis activity (Final report). Submitted to the American Soybean Association and the United Soybean Board. John C. Baize Associates.

Barowicz T. (1999). Tłuszcz dawki pokarmowej a wartość dietetyczna produktów pochodzenia zwierzęcego. Przegląd Hodowlany. Wars. No. 11.

Britzman D.G. (1994). Soybean Meal An Exellent Protein Source for Poultry Feeds. Technical Bulletin. American Soybean Association and United Soybean Board. John C. Baize and Associaties.

Busboom J.R., Rul D.C., Colin D., Heald T., Mazhar A. (1991). Growth, carcass characteristics and lipid composition of adipose tissue and muscle of pigs feed canola. J. Anim. Sci. 69.

Chachułowa J. (1997). Pasze. Praca zbiorowa. SGGW. Warszawa.

Drozdowski B. (1988). Lipidy. Chemia żywności. PWN. Warszawa.

Drzewieniecka B. (2017). Wpływ czynników egzogennych w procesie przechowywania śruty sojowej. Food Quality and Safety - Analyses-Trends-Challenges. Commodity Science in research and practice. Kraków. pp. 93-103.

Gunstone F.D., Norris F.A. (1983). Lipids in foods. Chemistry, biochemistry and technology. Pergamon Press. London.

Gunstone F.D. (1984). Reaction of oxygen and unsaturated fatty acid. JAOCS. 61. 
Jung M.Y., Bock J.Y., Back I.O., Lee T.K., Kim Y.M. (1997). Pyrazine contents and oxidative stabilities of roasted soybean oils. Food Chemistry. Vol. 60. London. No. 1.

Kearney J. (2010). Food consumption trends and drivers. Phil.Trans. R. Soc.B. 365,27932807.

Kwietniak M., Harenza T. (1990). Autooksydacja pasz i przeciwutleniacze. Centralne Laboratorium Przemysłu Paszowego. Lublin.

Lempka A. (1985). Towaroznawstwo. Produkty spożywcze. Praca zbiorowa. PWE.

Mateos G.G., Garcia P., Medel P. (1996). The use fullfat soybeans in diets for poultry. Second International Fullfat Soya Conference. Processing, Quality Control, Utilization. American Soybean Association and United Soybean Board. August 21-24. Budapest.

Matyka S. (2000). Utlenianie tłuszczów - przeciwutleniacze. Pasze Przemysłowe. No. 4-5.

Mińkowski K., Grześkiewicz S., Jerzewska M. (2011). An assessment of nutritional value of plant oils with a large content of linoleic acids based on the composition of fatty acids, tocopherols and sterols. Żywność. Nauka. Technologia. Jakość. 75(2). 124-135.

Myer R.O., Johnson D.D., Knauft D.A., Gorbet D.W., Brendemuhl J.H., Walker W.R. (1992). Effect pf feeding high-oleic-acid peanuts to growing-finishing swine on resulting carcass and meat quality characteristics. J. Anim. Sci. 70.

Nederal S., Skevin D., Kraljić K., Obranowić M., Papesa S., Bataljaku A. (2012). Chemical composition and oxidative stability of roasted and cold pressed pumpkin seed oils. Journal of the American Oil Chemists Society, 89(9). 1763-1770.

Orsavova J., Misurcova L., Vavra Ambrozova J., Vicha R., Mlcek J. (2015). Fatty acids composition of vegetable oils and its contribution to dietary energy intake and dependence of cardiovascular mortality on dietary intake of fatty acids. Int $\mathrm{J}$ Mol Sci. 16(6). 12871-12890.

Rabrenović B., Dimić E.B., Novakowić M.M., Tessević V.V., Basić N. (2014). The most important bioactive components of cold pressed oil from different pumpkin (Cucurbita pepo L.) seeds. LWT - Food Sci. Technol. 55. 521-527.

Sikorski Z.E. (1994). Chemiczne i funkcjonalne właściwości składników żywności. WNT.

Thakkar A. (2014). Study of effect of temperature on shelf stability of soybean-corn oil blends. International Journal of Theoretical \& Applied Sciences. 6 (1). 14-19.

Vaidya B., Jong-Bang E. (2013). Effect of temperature on oxidation kinetics of walnut and grape seed oil. Food Sci. Biotechnol. 22 (S). 273-279.

Walczyński S. (1993). Liczba kwasowa a pastewna użyteczność tłuszczów. Pasze Przemysłowe. No 7-8.

Wang D., Thakker C., Liu P., Bennett G.N., San K.Y. (2015). Efficient production of free fatty acids from soybean meal carbohydrates, Biotechnol and Bioeng. 112(11), 2324-2333. 